\title{
Ethnographic Study on the Existence of Traditional Game in Lhokseumawe City
}

\author{
Ibrahim Chalid ${ }^{1, *}$ Ade Ikhsan Kamil ${ }^{2}$ Richa Meliza ${ }^{3}$ \\ ${ }^{l}$ Anthropology Departement, Faculty of Social and Political Science, Universitas Malikussaleh, Lhokseumawe, Aceh, \\ Indonesia \\ ${ }^{2}$ Anthropology Departement, Faculty of Social and Political Science, Universitas Malikussaleh, Lhokseumawe, Aceh, \\ Indonesia \\ ${ }^{3}$ Anthropology Departement, Faculty of Social and Political Science, Universitas Malikussaleh, Lhokseumawe, Aceh, \\ Indonesia \\ Email:Ibrahim.Chalid@unimal.ac.id
}

\begin{abstract}
This article focuses on the dynamics of games that are played in Aceh society and its changes within society's life in general. Which means this article would want to describe the existence of traditional games and the cause of their erosion by the changes within Aceh society's changes. With an ethnography approach, researcher attempt to describe diachronically the dynamics of traditional games and the changes within Aceh society. Researcher used participatory observation method and in-depth interview as well as literature study to understand the development changes of the traditional games done by research subject. This research explains that there are several traditional games still existing within Aceh society, such as 'maen guli' (marbles game), kites, 'maen canci pet' (hide and seek), 'chee-chee' (hopscotch). Traditional games are one of the forms of character building within Aceh society, from religion, cultural, social and educational aspects. These games are highly enjoyed by Aceh people, not only the children but also adults and parents love playing them. Even though empirical proof shows there are shift or gradual changes from traditional games to modern ones caused by increasingly advanced culture and technology.
\end{abstract}

Keywords: Traditional Game, Folklore, Ethnography, Cultural Shift, Character Building

\section{INTRODUCTION}

Traditional games within Aceh society that are played by everyone of all ages are one the results of cultural creation passed down from generation to generation. Several literatures show that games - modern or traditional - affect the development of children and community. Since the games act as stimuli for individuals and comparison with real-life everyday life. Other than creativity, games can also affect innovation and resilience as well as learning mediums about written rules and leadership.

Rapid informational technology development has an inevitable effect on children's development. Especially ever since COVID-19 started as a global catastrophe changed every aspect of people's live, including in Indonesia. One of the most visible change is the changes within national educational system that has to be adapted with health protocol in an effort to prevent and control the spread of COVID-19.
Before COVID-19 as a globally-affected pandemic, informational technology development is thought to be the culprit of children's development, especially with children that are thought to be deviant. Since the rapid development of the internet in the 2000s, Aceh has been an area with quite different historical chapters so informational technology development is thought to affect various existing cultural aspect. However, with schools' adaptation with health protocol policies by maximizing existing informational technologies, these days technological gadgets are an important medium to access learning media and change. Although researcher realizes there are gadget uses that are not in accordance with their actual use, they cause problems with children's development and how children differentiate online world with their own realities. Not only that, the use of smartphones with their readily-available and easily-used apps also cause several aspects of development, not only physical but also mental, including their socialization and communication skills within community. From the results of early observation 
that researcher did on the field (Lhokseumawe), researcher compares the use of smartphone in children before and after COVID-19 case were announced the first time in Aceh on March 2020. Before COVID-19, usually children used minimum four (4) hours in front of a computer on internet cafes or personal, familyowned smartphones. However, after COVID-19, Middle School-age children are used to using smartphones, especially with children from middle class families. However, to several parents that researcher met with, they said that the use of smartphones has become inevitable ever since the adaptation under COVID-19. According to them, children have to accept smartphones as part of their lives.

The problem is, as an effort to adapt the learning process during COVID-19 pandemic, children have been using smartphones excessively and in an uncontrollable way because of their spare times, that are more than usual. That causes several things that used to be considered negative to start to be accepted even though generally parents have not been accepting the current learning process that includes children intensive access to their smartphones. Since it has effects on children's development, parents are also concerned if the use of smartphones would cause the children's difficulty in communicating and interacting with their peers and the loss of quality times with parents. Not to mention, we know that there are other negative effects of excessive smartphone use. Since children would have chances to access internet contents that are not suitable for their age, and they have not developed their cognitive skills to filter appropriate information for their age group at the time.

With various effects and needs caused by the shift of the learning process due to the adaptation in accordance to COVID-19 health protocol, at the time, researcher, parents and various academicians were concerned with the use of smartphones as a result of currently significant informational technology development. Other than eroding community lifestyle, these changes can also cause children at the forefront of cultural acculturation that they might not understand fully yet. Because of that, these days various games that have been used as a medium for emotional, physical and creativity development are not so easy to be found. In the city area, outskirts or even suburbs of a city. The phenomenon that the researcher explained above is one of the current conditions and reality in Lhokseumawe city. maupun di sudut kota atau kawasan penyangga sebuah perkotaaan. Because of that, researchers posited that the condition before and after COVID-19 became a new and important fact is connected with the existence of traditional games, which correlated with the changes of people's perception in relation to the use of smartphones due to informational technology development.

\section{RESEARCH METHODS}

In this article researcher used ethnography as a method of data gathering and analysis as well as the key instrument of the entire article writing. The ethnography method that the writer used has a goal to describe holistically about the dynamics of traditional games in Lhokseumawe society. Which means, this research would describe in a comprehensive way about the existence of traditional game vis a vis modern games, and compare them with the condition before and after the COVID-19 pandemic in Aceh.

Other than that, the work to understand the answer, factors and why has traditional games been left behind becomes important, with the role of traditional games in children's behavioral development and children's interaction with their environment. In other words, researcher would like to obtain a full description about the existence of traditional games in the midst of their modern counterparts. Other than that, through this research it is expected that researcher would form a model or pattern that can be used to revitalize traditional games in Lhokseumawe city society.

Ethnography method is used as this research's approach because researcher would be the key and main instrument during the data gathering process. Researcher would be in the production and reproduction circle of meaning and discourse, which means researcher would, intensively, be within the social laboratorium which is the people's life which would be the research subject. To achieve that goal, researcher used several data gathering techniques in order to maximize primary and secondary data gathering, as well as qualitative and quantitative data needed.

\section{LANGUAGE, BEHAVIOR, AND CULTURE}

Cultural system that has been a part of a society as stated by Masinambow (1985) can be researched through representation of language and behavior of research subject. With the ability of humans to use symbols as a communication medium in social interaction as a focus point of the research process related to language, culture, and human behavior. Because of that, language (including body movement/non linguistic) as part of symbols, spoken or written becomes one of the aspect of humankind's most important culture. Language is a symbolic system, that can be understood after learned and used to express thoughts and feelings; narrating their experience and understanding of the past events. However it must be realized that language is not forever effective if not supported by behavior, since the socialization process does not alway happen with oral tradition but also practically through behaviors.

Concrete form of the implicit use of language and behavior can be seen within folk games. This is common since in folk or traditional games, language and behavior become two dominant components that are always found there. As part of the culture, the focus on folk games is also part of anthropologists' observations who made culture as part of their studies' objective.

Anthropology studies about language and behavior is compiled within folk games. It is mostly done by those who focuses on folklore studies. This is 
because of the function of folklores as a way to express to us in an implicit (such as folk stories, or folk games) or explicit (such as in proverb) way about the thought and behavioral pattern of a folk community in an effort to deal with life's problems. Other than that, folklores are also used to immortalize or express what were thought as important for the society's history.

Even though the term folklore is quite old, the term was first used in 1846 by William John Thomas, a British cultural expert. However in Indonesia, folklore is a currently developing discipline. The research within this discipline is of course, still quite rare. Several researches about folklore have been done by foreign scholars, especially Dutch scholars, such as G.A. Hazen(1897); J. Katz(1923); H. Kern (1887); and J. Hooykaas (1941 dan 1956.a); Th. Pigeaud (1929) who wrote about philology. It was then J.P.B. de Josselin de Jong (1929); Jane Be1o (1960) who compiled the materials in cultural anthropology. Dutch theologians also contributed to the writings about folklore, such as C. Poensen (1870); J. Kreemer (1888); P.J. Zoetmulder (1939); Roelof Goris (1973); A.C. Kruyt (1940). Contributing dance scholar in this study is K.E. Mershon(1971) and painter Walter Spies(1939) (read Danandjaya 1984:9).

Indonesian scholars have also compiled materials related to folklore studies, within their own studies, even if some only done so for their own hobbies and not in accordance to folklore study. These Indonesian scholars are RM. Poerbatjaraka (1940), Tjan Tjoe (1941) as philologists. Koentjaraningrat (1961); I Gusti Ngurah Bagus (1971) within cultural anthropology discipline and I Made Banden (1972) as part of dance study (Danandjaya 1984: 9).

Folklores in general and folk or traditional games in particular is not only a medium to spend spare time and to entertain themselves (self-amusement) but also have an educational cultural function (Indonesia, 1996). This can be inferred from the rules in folklore practice in form of games which reflect an adherence to commonly agreed upon rules and penalties for those who break the rules. Not only that, if in a folklore (in this case can be seen a lot in traditional games) there are players who do not follow the rules, then it would ruin the folklore system and the games would be something that are no longer fun. This shows that folklore has a recreational role in real life that the society who owns the game lives on.

Lately the development of folklore study is increasing as the time goes by. Several new studies related to it has been showing how the relation between children's character building through traditional game, especially to increase social skills (Perdani:2014), increasing health and intelligence (Juwairiah:2016), as well as implementation in the form of games for pedagogical enhancement (Yufitsa, Reshi dkk: 2016) as well as the culture shift of the game (Asmanidar:2017). However, through literature review that has been done, research in relation to the existence of traditional games is still very minimal, as well as their relation with children's anthropological development (ethnography method).

\section{THE EXISTENCE OF TRADITIONAL GAMES 4.1.1. Aceh Society Old Time Folk Games}

In a report before the Pekan Budaya Aceh (Aceh Cultural Week), Drs. T. Syamsuddin (1972) once reminded that cultural issues with all their complex definitions were a unique issue to be discussed. He himself believes (T. Syamsuddin, 1972) that culture is a factor that determines the direction and development of the nation in the future. Therefore, art is one of the many elements of culture, this includes traditional games.

Traditional games in Aceh society in the past were closely related to character building, community life, and as educational platforms that connected the past with the future that were useful for future generations. And through traditional games that the regularity of time and space in an effort to form norms becomes possible.

The trace of some activities that were previously categorized as games are now only left in archived research report sheets and books. The rest can only be seen performed by art communities in Aceh during cultural festivals.

In fact, when we read the foreword to Atjeh Jang Kaja Budaja's book written by Talsya (1972), then we will see how some traditional cultures from Aceh have become a nostalgia for the twilight of life that has become a dream for the author himself. The order of life from the morning time since we open our eyes till the night veiled the sky is always filled with fun, joy, faith for tomorrow, and historical and heroic narratives. He wrote the following (1972: 5):

"Bila Malam terang purnama, desa-desa di tanah atjeh senantiasa belangir pesta jang meriah, sehinga begitu indahnya malammalam begini. Kerap kali membuat wisatawan tertjengang mengaguminja.

Djika Senja telah berdjabat laru malam, rakjat Atjeh menghadapi berbagai kesibukan malam jang belangir aneka tjenderamata pelerai hati berupa aneka ragam kesenian asli ; tari-tari jang indah gemalai dan njanjian jang lembur mempesona menggema di berbagai pendjuru desa. Karena disamping tarian dan njanjian perdjuangan, sadjak-sadjak romantis menambah harumnya kesegaran malam.

Malahan, kelompok-kelompok dara jang menumbuk padi, itupun merupakan suatu fatamorgana yang paling romantis. Bunji alu menimpa lesung bersahut-sahutan masingmasing dengan lentun irama berbeda-beda diselang-seling tawariang dan senda-gurau para gadis yang sedang tumbuh dewasa dengan sejuta chajalan indah dalam otaknya. 
When the night filled with the full moon light, villages in the land of atjeh where paties are always lively, and thus the nights seemed so magnificent. The tourists were in awe every time they saw them.

When the dusk greeted the night, people of Atjeh were faced with the bustling night to create merchandise in a form of traditional arts; graceful dances and songs that echoed in across the village. Apart from dances and songs of battle, romantic poets filled the night with its fragrance.

The maidens who pounded the rice, it was the most romantic fatamorgana. the sound of alu (mortar) hitting lesung (pestle) in rhythm with another voice coming from the maidens telling jokes with millions of dreams inside their heads.

Such beauty comes from Talsya's (1972) imaginations of various games which are currently known as traditional games in the form of art which always accompany night time. Some of these traditional games as summarized are (1972: 10-44) (1) Seudati (Tari Kepahlawanan - Dance of the Heroes), Seudati is a dance that shows the heroism and masculinity of men. The game of Seudati is carried out by young men, although there are seudati played by young women, they are usually referred to as Laweuet. (2) Ratoeh Duek, a combination of rhythmic chorus of dance movements sung in a melodious voice between fellow players divided into three parts. (3) The games played with Rapa'i, such as Rapa'i Daboh, Rapa'i Pulot. Rapa'i provides a melody that sets the rhythm of the movement. (4) Pho or Bineueh, which is a dance performed by women of the same age. Bineueh comes from the Arabic language, banat, or binoe. (5) GRIMPHeNG, almost similar to Rapa'i Pulot. (6) Meuseukat, Dance. (7) Biula, a type of musical instrument, almost similar to the violin. (8) Suleng, Bangsi, Hareubab, Tjanang, Gong and Geundrang, musical instruments commonly used for art and rhyme games. (9) DIKe, the art of sound which is recited by a group of people simultaneously by memorizing poems and words of wisdom. (10) Nasip, (11) Hadih Madja, (12) Geudeu-Geudeu (Wrestling), (12) Haba Djameun, saga reading both about history and other themes such as romance, heroism and religious guidance.

\subsubsection{Traditional Games, Today}

There are so many traditional games, but the popularity of traditional games are starting to fade from time to time. In an era with increasingly sophisticated technological developments, traditional games are replaced by technology.

Traditional games, according to Dharmamulya (2008), are cultural elements that have a significant influence on psychological development, nature and social life of children in the future. As there are only a few traditional games that still exist today, one of which is maen guli (playing marbles), kite, 'maen canci pet' (hide and seek), chee-chee (hopscotch). Even though in reality the traditional games in the past were very diverse, including cato/mancala, rumoh-rumoh, tayo lele, peg lele, gaseng, and geunteut.

These varieties of traditional games were popular among Acehnese children in the past. Not only children who played these traditional games, but also adults would play the games in between work hours.

These traditional games are one of the activities that encourage and train children to interact with one another, socialize with neighbors and their peers. So that it can improve their communication skills and creativity.

Traditional games do not only provide fun for children but have a meaning in which there are values that are contained both in terms of religion, culture, ethics and norms. As Desmita said in Juwairiah (2016), games are one of the dominant forms of social activity during childhood. Where this will train a child to interact.

\subsubsection{Dynamics Changes of Traditional Games}

Game is a form of civilizations that is older than culture itself. This is in line with statements from Johan (1975) in Asmanidar (2017), "Play is older than culture, for culture however, inadequately defined, always presupposes human society, and animals have not waited for man to teach them their playing. We can safely assert, even, that human civilization has added non-essential feature to the general idea of play"

However, environmental influences are not always positive, there are also negative impacts from environmental influences, one of which is that children begin to recognize games from their peers or we often refer to them as teman bermain (play dates). First, children will get to know traditional games, gradually there will be changes or shifts in the times like today.

The influence of technology is a factor affecting how children play, where in the past they were familiar with traditional games but with a change in conditions before the internet until 2005, when internet has finally become a part of children's daily life. Children started to recognize WarNet (Warung internet/internet cafe). Online media is more practical and individualistic. In this problem, the influence of the nature of the child is closely related to the games played by the child. For example, in traditional games, children will be introduced to teamwork, as in the traditional Acehnese game "maen canci pet" or "petak umpet" (hide and seek)" in Indonesian, in this game children will often play together outside so that their social interactions tend to be stimulated.

In contrast with popular online games, such as "Mobile Legend" where this kind of games require a 
smartphone to play, and many other types of games that use virtual media as their media. However, there are many negative traits that may affect children's attitudes in online games, such as creating more individualistic traits in children, more aggressive attitudes, emotions, and ethics. Many cases of children with online game addiction lose respect for their parents, uncontrolled emotions in playing this feature can become a topic of conversation.

As the time goes by, the factors that influence the development or change of socio-cultural dynamics occur because of human dependence on sophisticated technologies. Traditional games will stimulate creative minds, while modern games tend to form children to be individualistic individuals. So that the dynamics of changing this traditional game experiences a gradual shift in the lives of children today.

\section{CONCLUSION}

There are several conclusions based on facts and data that I have gathered in relation to the existence of traditional games.

Firstly, the existence of old times traditional games have been very helpful for the people, especially Aceh people in the process of children's character building in social, cultural, and educational aspects.

Secondly, traditional games are legendary games. Which means that it is not only children who play the game, but also teenagers and adults. It is because traditional games are not only seen from an individual's age but also their creativity and social and cultural interaction in people's environment.

Third, currently there are gradual shift in traditional games and slowly disappearing from children's environment as an effect of environment and advancement of technology. This causes the shift of dynamics in traditional games to modern games.

\section{REFERENCES}

[1] Asmanidar. 2017. Pergesaran Budaya Permainan Anak di Aceh (Suatu Tinjauan Sosiologi Antropologi). Gender Equality: International Journal of Child and Gener Studies. Vol.3, No.2. hal. 88-98.

[2] Danandjaja, James. 1984. Folklor Indonesia: Ilmu Gossip, Dongeng dan lain -lain. Jakarta; Grafities.

[3] Danandjaja, James.1988. Antropologi Psikologi: Teori, Metode dan Perkembangannya Jakarta; Rajawali Pers.

[4] Juwairiah. 2016. Meuen Galah: Permainan Tradisional Aceh Sebagai Media untuk Meningkatkan Kesehatan dan Kecerdasan Anak Usia Dini. Vol. 1 No.2. 119-132
[5] Kling, Zainal. 1985. Strukturalisme dan Pengajian Masyarakat Melayu dalam Struktural Suatu Tinjauan Multidisiplin. Nik Safiah Karim (Editor). Kuala Lumpur; Jabatan Pengajian Melayu Universitas Malaya. HIm 1-23.

[6] Masinambaow. 1985. Persfektif Kebahasaan Terhadap Kebudayaan, dalam Persepsi Masyarakat Tentang Kebudayaan, Alfian ed. Jakarta; PT. Gramedia

[7] Perdani, Putri Admi. 2014. Peningkatan Keterampilan Sosial Anak Melalui Permainan Tradisional. Jurnal Pendidikan Anak Usia Dini. Vol 8 (1) Hal. 129-136.

[8] Mely G. Tan. Masalah Perencanaan Penelitian, dalam Koentjaraningrat. 1991. Metode-Metode Penelitian Masyarakat, Jakarta: Gramedia Pustaka Utama.

[9] Yufitsa, Reshi. Dkk. 2016. Implementasi Permainan Tradisional Aceh di Paud IT Al-Fatih Banda Aceh. Jurnal Ilmiah Mahasiswa Pendidikan Anak Usia Dini, 1 (1) 68-75. 